\title{
FORMULATION AND EVALUATION ORAL DISPERSIBLE TABLET OF CINNARIZINE
}

\author{
Dr. M M Gupta ${ }^{1}$, Vishal Patel ${ }^{2 *}$ \\ ${ }^{1}$ Principal, Jaipur College of Pharmacy, Jaipur, Rajasthan \\ ${ }^{2}$ M Pharm (Pharmaceutics) Scholar, Jaipur College of Pharmacy, Jaipur, Rajasthan \\ Corresponding Author’s Email: rx.vishal1990@gmail.com,Vishalpatel_2502@yahoo.com,Phone: +918000140915
}

\begin{abstract}
Oral Dispersible tablets (ODTs) constitute an innovative dosage form, which overcomes the problem of swallowing and provides a quick onset of action. The aim of the proposed work is to formulate fast dissolving tablets of Cinnarizine for rapid dissolution of drug and absorption, which may produce rapid onset of action in the treatment of motion sickness. For this purpose the tablets of Cinnarizine were prepared by Effervescent method, Super disintegrants addition method and Sublimation method. Cinnarizine is an Antihistamines drug has been used for the treatment of motion sickness. Cinnarizine is poorly soluble in water making it a potent candidate fast-dissolving drug delivery system.

Key word: ODT, Cinnarizine, Granules, Superdisintegrants,
\end{abstract}

\section{INTRODUCTION}

Recent advances in Novel Drug Delivery System (NDDS) aims to enhance safety and efficacy of drug molecule by formulating a convenient dosage form for administration and to achieve better patient compliance. One such approach is Fast Dissolving Tablet (ODT). ${ }^{1-4}$

The term ODT appears in the European Pharmacopoeia defined as "uncovered tablet for buccal cavity, where it disperses before ingestion". The solid ODT dosage form turns into a soft paste or liquid form for easy swallowing, and thus it is free of suffocation risk. ODTs are beneficial for paediatric, geriatric, schizophrenic, bedridden patients and those with Parkinsonism or developmentally disabled patients with persistent nausea and patients who have little or no access to water. ODT will avoid missing out of dose even during travelling, busy or other situations where there is no access to water. They undergo disaggregation in the mouth when in contact with the saliva in less than 60 seconds, preferably in less than 40 seconds, forming a suspension which is easy to swallow. A major claim of some oral dispersible tablets is increased bioavailability compared to traditional tablets because some of the drugs are absorbed from the mouth, pharynx and esophagus as the saliva passes down into the stomach. In such cases, the bioavailability of the drug is significantly increased over those observed in the conventional tablet dosage form. ${ }^{5-8}$

\section{MATERIALS AND METHODS}

\section{Sublimation method}

Specified quantity of Cinnarizine, camphor, mannitol, aspartame, talc and magnesium stearate were weighed accurately and were passed through 60 \# screen prior to mixing. All the materials were transferred to mortar and triturated till it mixed uniformly. The resulting powder mixture was compressed into tablets using single punch tablet machine. The tablets were dried at $60^{\circ} \mathrm{C}$ oven till constant weigh obtained. ${ }^{9-10}$

\section{EVALUATION OF POWDER BLEND}

Table 1: Evaluation of the Powder Blend

\begin{tabular}{|c|c|c|c|c|c|}
\hline Batch code & Bulk density & Tapped density & Angle of repose & \% compressibility & Hausner ratio \\
\hline B1 & 0.58 & 0.68 & 25.61 & 14.71 & 1.172 \\
\hline B2 & 0.56 & 0.67 & 25.07 & 16.42 & 1.196 \\
\hline B3 & 0.55 & 0.64 & 24.68 & 14.06 & 1.164 \\
\hline B4 & 0.53 & 0.62 & 24.50 & 14.52 & 1.170 \\
\hline B5 & 0.52 & 0.59 & 23.82 & 11.86 & 1.135 \\
\hline B6 & 0.50 & 0.57 & 23.49 & 12.28 & 1.140 \\
\hline B7 & 0.58 & 0.70 & 30.05 & 17.14 & 1.207 \\
\hline B8 & 0.58 & 0.71 & 30.64 & 18.31 & 1.224 \\
\hline B9 & 0.59 & 0.73 & 31.45 & 19.18 & 1.237 \\
\hline
\end{tabular}


Formulation of Oral Dispersible Tablet

Table 2: Formulation of ODT

\begin{tabular}{|c|c|c|c|c|c|c|c|c|c|}
\hline Ingredient & B1 & B2 & B3 & B4 & B5 & B6 & B7 & B8 & B9 \\
\hline Cinnarizine & 25 & 25 & 25 & 25 & 25 & 25 & 25 & 25 & 25 \\
\hline Crospovidone & 10 & 15 & 20 & & - & - & - & - & - \\
\hline $\begin{array}{c}\text { Croscarmellose } \\
\text { sodium }\end{array}$ & - & - & - & 10 & 15 & 20 & - & - & - \\
\hline L-HPC & - & - & - & - & - & - & 10 & 15 & 20 \\
\hline Avicel 102 & 60 & 60 & 60 & 60 & 60 & 60 & 60 & 60 & 60 \\
\hline Aspartame & 2 & 2 & 2 & 2 & 2 & 2 & 2 & 2 & 2 \\
\hline Talc & 4 & 4 & 4 & 4 & 4 & 4 & 4 & 4 & 4 \\
\hline Mg stearate & 2 & 2 & 2 & 2 & 2 & 2 & 2 & 2 & 2 \\
\hline Mannitol up to... & 200 & 200 & 200 & 200 & 200 & 200 & 200 & 200 & 200 \\
\hline
\end{tabular}

\section{EVALUATION OF ORAL DISPERSIBLE TABLETS}

Table 3: physical parameters of mouth dissolving Tablet

\begin{tabular}{|c|c|c|c|c|c|c|c|}
\hline $\begin{array}{c}\text { Batch } \\
\text { Code }\end{array}$ & $\begin{array}{c}\text { Weight } \\
\text { Variation }\end{array}$ & $\begin{array}{c}\text { Thickness } \\
(\mathbf{m m})\end{array}$ & $\begin{array}{c}\text { Hardness } \\
\left(\mathbf{K g}_{\mathbf{c m}} \mathbf{)}\right.\end{array}$ & $\begin{array}{c}\text { Friability } \\
(\mathbf{\%})\end{array}$ & $\begin{array}{c}\text { In-Vitro Disin. } \\
\text { Time (Sec) }\end{array}$ & $\begin{array}{c}\text { Wetting } \\
\text { Time (Sec) }\end{array}$ & Assay (\%) \\
\hline B1 & pass & 2.56 & 2.5 & 0.73 & $48.3 \pm 1.53$ & $69.8 \pm 1.04$ & 98.14 \\
\hline B2 & pass & 2.57 & 2.5 & 0.76 & $34.0 \pm 1.00$ & $35.0 \pm 0.95$ & 99.02 \\
\hline B3 & pass & 2.60 & 2.5 & 0.79 & $28.6 \pm 1.22$ & $32.4 \pm 1.15$ & 100.51 \\
\hline B4 & pass & 2.63 & 2.5 & 0.74 & $59.4 \pm 2.42$ & $89.0 \pm 0.85$ & 98.91 \\
\hline B5 & pass & 2.65 & 3.0 & 0.78 & $32.6 \pm 1.25$ & $66.0 \pm 1.35$ & 100.04 \\
\hline B6 & pass & 2.66 & 2.5 & 0.80 & $36.6 \pm 2.12$ & $70.4 \pm 1.48$ & 99.86 \\
\hline B7 & pass & 2.51 & 3.0 & 0.69 & $59.7 \pm 2.46$ & $67.8 \pm 0.35$ & 98.92 \\
\hline B8 & pass & 2.52 & 2.5 & 0.65 & $33.5 \pm 0.50$ & $41.7 \pm 1.45$ & 101.05 \\
\hline B9 & pass & 2.54 & 2.5 & 0.66 & $25.3 \pm 0.58$ & $29.1 \pm 1.05$ & 100.34 \\
\hline
\end{tabular}

\section{In-vitro Disintegration time}

The in-vitro disintegration time was determined using disintegration test apparatus. A tablet was placed in each of the six tubes of the apparatus and one disc was added to each tube. The time in seconds taken for complete disintegration of the tablet with no palatable mass remaining in the apparatus was measured in seconds. ${ }^{11}$

Table 4: Evaluation parameter of mouth dissolving tablets prepared by different method

\begin{tabular}{|c|c|c|c|}
\hline Parameters & Effervescent & Superdisintegrant addition & Sublimation \\
\hline Hardness $\left(\mathrm{kg} / \mathrm{cm}^{2}\right)$ & 2.5 & 2.5 & 2.5 \\
\hline Friability (\%) & 0.625 & 0.764 & 0.861 \\
\hline Disintegration time (s) & 92 & 34 & 132 \\
\hline
\end{tabular}

The disintegration time and friability were evaluated and results were graphically summarized in the Figure 1 and Figure 2

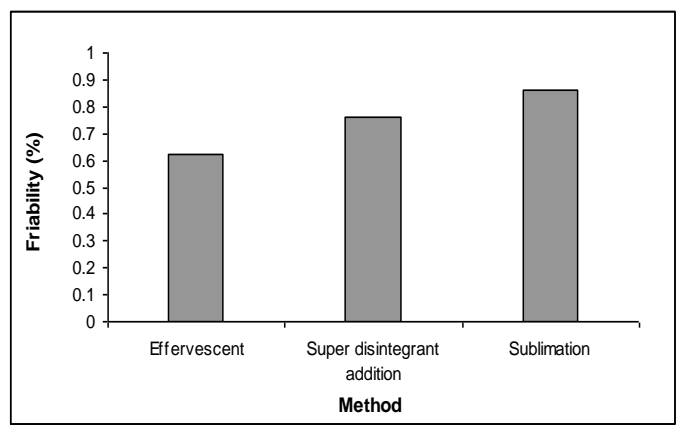

Figure 1: Column graph of friability of mouth dissolving tablets prepared by different method

(C) 2011, JDDT. All Rights Reserved

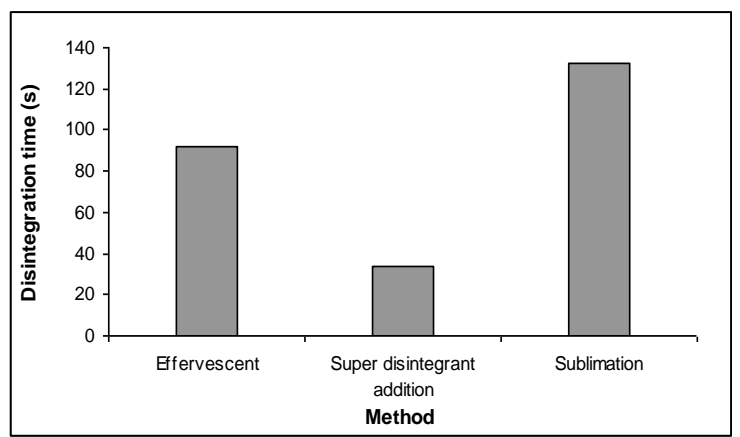

Figure 2: Column graph of disintegration time of mouth dissolving tablets prepared by different method 
The friability of tablets, prepared by various methods was shown in Fig. No 1. Friability of all batches was in the range of standard limit (less than 1\%) and no more significant difference. It can be concluded that tablets prepared by superdisintegrant addition method has less disintegration time than other method. ${ }^{12-15}$

\section{STUDY OF THE EFFECT OF CONCENTRATION OF AVICEL PH 102}

The intermediate concentration of the diluent (Avicel PH 102), that is, $20-50 \%$ of the tablet weight was selected from the trial series. These trial batches were prepared by super disintegrant addition method with same process as above. ${ }^{16-17}$

Table 5: Composition of formulation of Trial series

\begin{tabular}{|c|c|c|c|c|}
\hline Ingredient & T1 & T2 & T3 & T4 \\
\hline Cinnarizine & 25 & 25 & 25 & 25 \\
\hline Crospovidone & 15 & 15 & 15 & 15 \\
\hline Avicel PH 102 & 40 & 60 & 80 & 100 \\
\hline Aspartame & 2 & 2 & 2 & 2 \\
\hline Talc & 4 & 4 & 4 & 2 \\
\hline Mg stearate & 2 & 2 & 200 & 200 \\
\hline Mannitol up to... & $200 \quad$ All the quantities are in mg.
\end{tabular}

These tablets were evaluated for hardness, friability and disintegration time. The procedure was same as above evaluation tests.

Table 6: Evaluation parameter of Trial series

\begin{tabular}{|c|c|c|c|c|}
\hline Parameter & T1 & T2 & T3 & T4 \\
\hline Hardness $\left(\mathrm{kg} / \mathrm{cm}^{2}\right)$ & 2.5 & 2.5 & 2.5 & 2.5 \\
\hline Friability $(\%)$ & 2.24 & 0.76 & 0.62 & 0.45 \\
\hline Disintegration time $(\mathrm{s})$ & 27 & 34 & 48 & 64 \\
\hline
\end{tabular}

The friability and disintegration time were evaluated and results are graphically summarized in the Fig. No 3 and Fig. No 4.

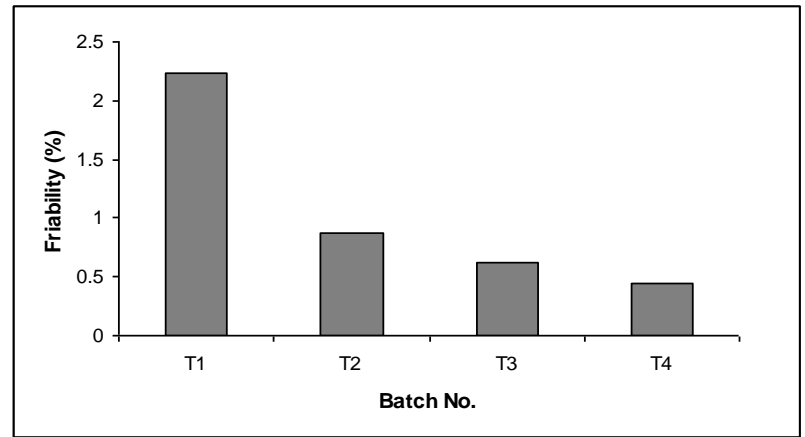

Figure 3: Column graph of the \% Friability of trial series

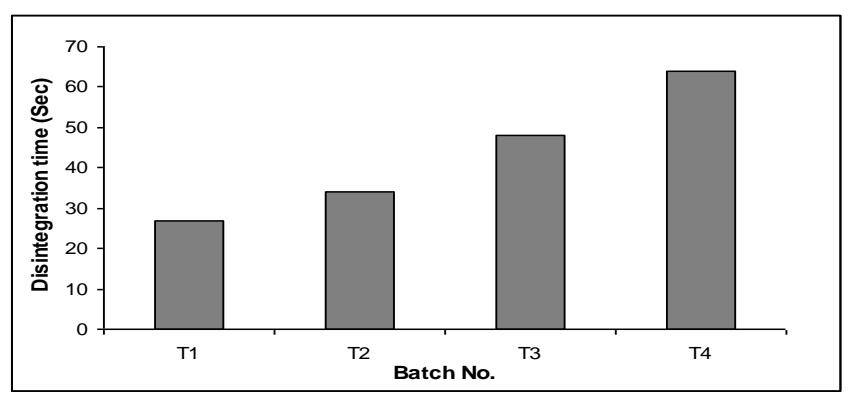

Figure 4: Column graph of the Disintegration time (Sec) of trial series

\section{In-Vitro drug release:}

Release of the drug in vitro, was determined by estimating the dissolution profile.

\section{Dissolution test:}

Standard USP or IP dissolution apparatus have been used to study in vitro release profile using rotating paddle.In vitro release rate study of mouth dissolving tablet of Cinnarizine was carried out using the Apparatus 2 (Paddle apparatus) method. The dissolution apparatus was covered with the black color polythine to protect the solution from light. The dissolution test was carried out using $900 \mathrm{ml}$ of $0.1 \mathrm{~N} \mathrm{HCl}$, at $37 \pm 0.5^{\circ} \mathrm{C}$ and $50 \mathrm{rpm}$. A sample $(5 \mathrm{ml})$ of the solution was withdrawn from the dissolution apparatus at 2, 4, 6, 8 and $10 \mathrm{~min}$ and withdrawn volume was replaced with fresh dissolution media. ${ }^{18-20}$

The withdrawn samples diluted with dissolution medium and then filter it with whattman filter paper and assayed at $253.5 \mathrm{~nm}$. The \% release of Cinnarizine was calculated. 
Table 6: Percentage Cumulative drug release profile of batch B1

\begin{tabular}{|c|c|c|c|c|c|c|}
\hline $\begin{array}{c}\text { Time } \\
(\mathbf{m i n})\end{array}$ & $\begin{array}{c}\text { Absorb } \\
\text { ance }\end{array}$ & $\begin{array}{c}\text { Concentratio } \\
\mathbf{n}(\boldsymbol{\mu g} / \mathbf{m l})\end{array}$ & $\begin{array}{c}\text { Amt. in 5 ml } \\
(\mathbf{m g} / \mathbf{m l})\end{array}$ & $\begin{array}{c}\text { Amt. in 900 ml } \\
(\mathbf{m g} / \mathbf{m l})\end{array}$ & $\begin{array}{c}\text { Cumulative drug release } \\
\text { in 900 ml (mg) }\end{array}$ & $\begin{array}{c}\text { Cumulative \% } \\
\text { drug release }\end{array}$ \\
\hline 0 & 0 & 0 & 0 & 0 & 0 & 0 \\
\hline 2 & 0.0764 & 1.46 & 0.0073 & 13.12 & 13.12 & 52.49 \\
\hline 4 & 0.1178 & 2.25 & 0.0112 & 20.23 & 20.24 & 80.96 \\
\hline 6 & 0.1387 & 2.65 & 0.0132 & 23.82 & 23.84 & 95.36 \\
\hline 8 & 0.1422 & 2.71 & 0.0136 & 24.42 & 24.46 & 97.82 \\
\hline 10 & 0.1425 & 2.72 & 0.0136 & 24.48 & 24.52 & 98.08 \\
\hline
\end{tabular}

Table 7: Percentage Cumulative drug release profile of batch B2

\begin{tabular}{|c|c|c|c|c|c|c|}
\hline $\begin{array}{c}\text { Time } \\
(\mathbf{m i n})\end{array}$ & $\begin{array}{c}\text { Absorb } \\
\text { ance }\end{array}$ & $\begin{array}{c}\text { Concentratio } \\
\mathbf{n}(\boldsymbol{\mu g} / \mathbf{m l})\end{array}$ & $\begin{array}{c}\text { Amt. in 5 ml } \\
(\mathbf{m g} / \mathbf{m l})\end{array}$ & $\begin{array}{c}\text { Amt. in 900 ml } \\
(\mathbf{m g} / \mathbf{m l})\end{array}$ & $\begin{array}{c}\text { Cumulative drug release } \\
\text { in 900 ml } \mathbf{( m g})\end{array}$ & $\begin{array}{c}\text { Cumulative \% } \\
\text { drug release }\end{array}$ \\
\hline 0 & 0 & 0 & 0 & 0 & 0 & 0 \\
\hline 2 & 0.0968 & 1.85 & 0.0092 & 16.63 & 16.63 & 66.50 \\
\hline 4 & 0.1262 & 2.41 & 0.0120 & 21.68 & 21.68 & 86.74 \\
\hline 6 & 0.1416 & 2.70 & 0.0135 & 24.32 & 24.34 & 97.37 \\
\hline 8 & 0.1438 & 2.74 & 0.0137 & 24.70 & 24.73 & 98.93 \\
\hline 10 & 0.1439 & 2.75 & 0.0137 & 24.72 & 24.76 & 99.06 \\
\hline
\end{tabular}

Table 8: Percentage Cumulative drug release profile of batch B3

\begin{tabular}{|c|c|c|c|c|c|c|}
\hline $\begin{array}{c}\text { Time } \\
(\mathbf{m i n})\end{array}$ & $\begin{array}{c}\text { Absorb } \\
\text { ance }\end{array}$ & $\begin{array}{c}\text { Concentratio } \\
\mathbf{n}(\boldsymbol{\mu g} / \mathbf{m l})\end{array}$ & $\begin{array}{c}\text { Amt. in 5 ml } \\
(\mathbf{m g} / \mathbf{m l})\end{array}$ & $\begin{array}{c}\text { Amt. in 900 ml } \\
(\mathbf{m g} / \mathbf{m l})\end{array}$ & $\begin{array}{c}\text { Cumulative drug release } \\
\text { in 900 ml }(\mathbf{m g})\end{array}$ & $\begin{array}{c}\text { Cumulative \% } \\
\text { drug release }\end{array}$ \\
\hline 0 & 0 & 0 & 0 & 0 & 0 & 0 \\
\hline 2 & 0.1021 & 1.95 & 0.0097 & 17.54 & 17.54 & 70.15 \\
\hline 4 & 0.1294 & 2.47 & 0.0123 & 22.23 & 22.23 & 88.94 \\
\hline 6 & 0.1452 & 2.77 & 0.0139 & 24.94 & 24.96 & 99.84 \\
\hline 8 & 0.1459 & 2.78 & 0.0139 & 25.06 & 25.10 & 100.38 \\
\hline 10 & 0.146 & 2.79 & 0.0139 & 25.08 & 25.13 & 100.50 \\
\hline
\end{tabular}

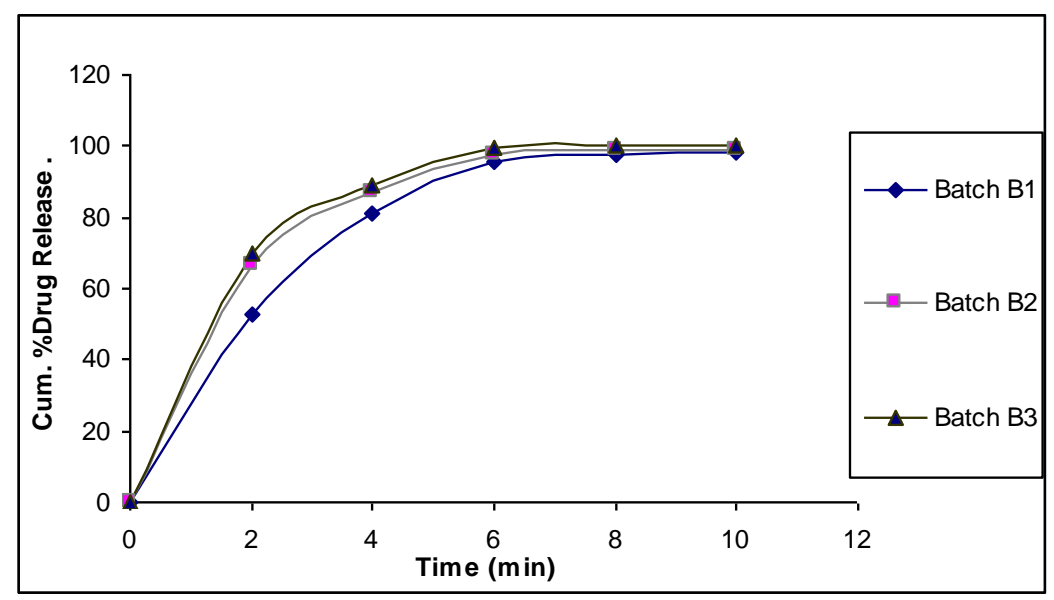

Figure 5: Cumulative drug release profile of batch B1, B2 and B3 
Table 9: Percentage Cumulative drug release profile of batch B9

\begin{tabular}{|c|c|c|c|c|c|c|}
\hline $\begin{array}{c}\text { Time } \\
(\mathbf{m i n})\end{array}$ & Absorbance & $\begin{array}{c}\text { Concentration } \\
(\boldsymbol{\mu g} / \mathbf{m l})\end{array}$ & $\begin{array}{c}\text { Amt. in 5 ml } \\
(\mathbf{m g} / \mathbf{m l})\end{array}$ & $\begin{array}{c}\text { Amt. in 900 ml } \\
(\mathbf{m g} / \mathbf{m l})\end{array}$ & $\begin{array}{c}\text { Cumulative drug } \\
\text { release in 900 ml (mg) }\end{array}$ & $\begin{array}{c}\text { Cumulative \% } \\
\text { drug release }\end{array}$ \\
\hline 0 & 0 & 0 & 0 & 0 & 0 & 0 \\
\hline 2 & 0.1211 & 2.31 & 0.0116 & 20.80 & 20.80 & 83.20 \\
\hline 4 & 0.1397 & 2.67 & 0.0133 & 23.99 & 24.01 & 96.02 \\
\hline 6 & 0.1452 & 2.77 & 0.0139 & 24.94 & 24.96 & 99.86 \\
\hline 8 & 0.1456 & 2.78 & 0.0139 & 25.01 & 25.05 & 100.19 \\
\hline 10 & 0.1455 & 2.78 & 0.0139 & 24.99 & 25.04 & 100.17 \\
\hline
\end{tabular}

\section{COMPARISON OF BEST FORMULATED TABLET WITH MARKETED TABLET}

The best formulated tablet was then compared with marketed tablet STUGERON 25mg. Formulation B9 was compared with marketed tablet for in vitro dissolution study.

Table 10: Percentage Cumulative drug release profile of Marketed Tablet

\begin{tabular}{|c|c|c|c|c|c|c|}
\hline $\begin{array}{c}\text { Time } \\
(\mathbf{m i n})\end{array}$ & Absorbance & $\begin{array}{c}\text { Concentration } \\
(\boldsymbol{\mu g} / \mathbf{m l})\end{array}$ & $\begin{array}{c}\text { Amt. in 5 ml } \\
(\mathbf{m g} / \mathbf{m l})\end{array}$ & $\begin{array}{c}\text { Amt. in 900 ml } \\
(\mathbf{m g} / \mathbf{m l})\end{array}$ & $\begin{array}{c}\text { Cumulative drug } \\
\text { release in 900ml (mg) }\end{array}$ & $\begin{array}{c}\text { Cumulative \% } \\
\text { drug release }\end{array}$ \\
\hline 0 & 0 & 0 & 0 & 0 & 0 & 0 \\
\hline 2 & 0.0326 & 0.62 & 0.0031 & 5.60 & 5.60 & 22.40 \\
\hline 4 & 0.0365 & 0.70 & 0.0035 & 6.27 & 6.27 & 25.09 \\
\hline 6 & 0.0462 & 0.88 & 0.0044 & 7.94 & 7.94 & 31.77 \\
\hline 8 & 0.0602 & 1.15 & 0.0057 & 10.34 & 10.35 & 41.40 \\
\hline 10 & 0.0731 & 1.40 & 0.0070 & 12.56 & 12.57 & 50.29 \\
\hline 15 & 0.0993 & 1.90 & 0.0095 & 17.06 & 17.08 & 68.32 \\
\hline 30 & 0.1307 & 2.49 & 0.0125 & 22.45 & 22.48 & 89.93 \\
\hline 45 & 0.1453 & 2.77 & 0.0139 & 24.96 & 25.00 & 100.01 \\
\hline
\end{tabular}

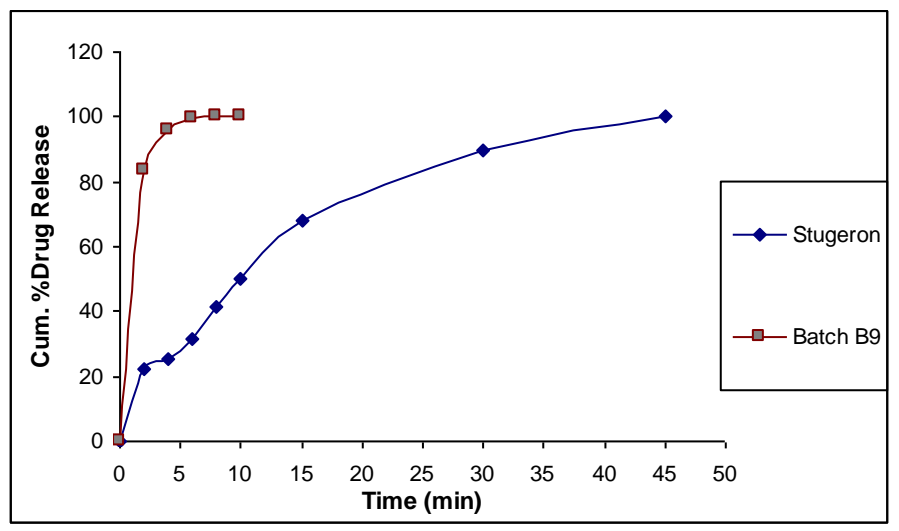

Figure 6: Comparison of in-vitro dissolution of B9 with marketed tablet

\section{SUMMARY AND CONCLUSION}

The present study was undertaken with an aim to formulate and evaluate Fast Dissolving tablets of Cinnarizine using Sublimation method with the addition of superdisintegranting agents. To increase the dissolution rate of poorly soluble drug Cinnarizine, by using the addition of Avicel 102 as Superdisintegrants. Preformulation study was carried out initially and results directed for the further course of formulation. Various formulations of Fast Dissolving tablets Cinnarizine were formulated by using various super Disintegrants- 
Crosspovidone, Sodium Starch Glycolate, Crosscarmellose Sodium. The tablets were evaluated for physical parameter such as Hardness, thickness, weight variation, friability, invitro disintegration, wetting time and In-Vitro Dissolution.

\section{REFERNCES}

1. Brahmankar D. M., Jaiswal S.B., Biopharmaceutics \& Pharmaceutics, First Edition, 1995, 335.

2. Howard C. Ansel, Nicholas G. Popvich, Loyd V. Allen, Pharmaceutical Dosage Forms and Drug Delivery System, First Edition, 1995, 78.

3. S. S. Biradar, S. T. Bhagavati and I. J. Kuppasad, Fast Dissolving Drug Delivery Systems: A Brief Overview, Internet J. Pharmacology, 2006, 4(2).

4. Kuccherkar B.S., Badhan A.C., Mahajan H.S., Mouth dissolving tablets: A novel drug delivery system, Phrma Times, 2003, 35, 3-10.

5. Kaushik D, Dureja H., Saini T. R., Mouth Dissolving Tablets: A review, Indian Drugs, 2004, 41(4), 187-193.

6. Amin A. F., Shah T. J., Bhadani M. N., Patel M. M., Emerging trends in orally disintegrating tablets, www.pharminfo.net, 2005.

7. Renon J. P. and Corveleyn S., Freeze-dried rapidly disintegrating tablets, US Patent No. 6,010,719, 2000

8. Lailla J. K., Sharma A. H., Freeze-drying and its applications, Indian Drugs, 1993, 31, 503-513.

9. Seager H., Drug delivery products and zydis fast dissolving dosage form, J. Pharm. Phamacol., 1998, 50, 375-382.

10. Masaki K., Intrabuccaly disintegrating preparation and production, US Patent No. 5,466,464, 1995.

11. Pebley W. S., Jager N. E. and Thompson S. J., Rapidly disintegrating tablets, US Patent No. 5,298,261, 1994.
Disintegration time of optimized formulation B9 was compared to conventional tablets, where it observed that disintegration time less than market preparation.

12. Allen L. V. and Wang B., Method of making a rapidly dissolving tablet, US Patent No. 5,635,210, 1997.

13. Allen L. V. and Wang B., Process for making a particulate support matrix for making rapidly dissolving tablets, US Patent No. 5,587,180, 1996.

14. Heinmann H. and Rothe W., Preparation of porous tablets, US Patent No. 3,885,026, 1975.

15. Knistch K.W., Production of porous tablets, US Patent No. 4,134,843, 1979.

16. Roser B. J. and Blair J., Rapidly soluble oral dosage form, method of making same and composition, US Patent No. $5,762,961,1998$

17. Lachmann L., Liebermann H. A. and Kiang J.L., The theory and practice of Industrial Pharmacy, Third Edition, Varghese Publishing House, Bombay, 1998, 430-440.

18. Yarwood R. J., Kearny K. and Thomson A.R., Process for preparing solid dosage form for unpalatable pharmaceuticals, US Patent No. 5,738,875, 1998.

19. Parul B. Patel, Amit Chaudhary and G. D. Gupta, Fast Dissolving Drug Delivery Systems: An Update, www.pharmainfo.net, 2006.

20. Suresh B. Borsadia, David Halloran and James L. Osborne, Quick-dissolving films - A novel approach to drug delivery, www.drugdeliverytech.com, 